\title{
5.6 Підходи до оцінки ефективності стратегії розвитку організації
}

Постановка проблеми. У сучасних умовах формування ринкових економічних відносин бізнес відіграє важливу роль як у зарубіжних країнах, так i в Україні. Саме підприємництво надає можливості здійснити структурну перебудову економіки і наситити всі види ринків товарами чи послугами в короткі терміни. Тенденція зростання складності та невизначеності зовнішнього та внутрішнього середовища функціонування суб'єктів господарювання стає однією з ключових проблем ритмічного та стійкого розвитку бізнесу. Рішення проблеми розробки інструментів стратегічного планування $\epsilon$ особливо важливим. Рішення, яке приймається менеджерами частіше в такій ситуації, обмежується підвищенням ефективності фінансової діяльності, і воно має ефект, але на короткий термін. Довгострокове планування змушує менеджерів розробляти більш гнучкі цілі та формулювати проблему під впливом змін внутрішніх та зовнішніх умов функціонування. У той же час, стикаючись із жорсткою ринковою конкуренцією, підприємства повинні оптимізувати стратегічну роботу, посилюючи синергію всіх сфер своєї діяльності. За таких обставин керівництво підприємств має сформувати набір цілей розвитку для кожної діяльності, яка буде спрямована на досягнення спільної стратегічної ефективності, а також виявити синергічні зв'язки між підрозділами та розвивати ïx. Рішення проблеми вимагає створення незалежної системи підтримки прийняття рішень для координації та контролю діяльності всіх структурних підрозділів. Створення та підтримка такої координації між стратегічними ресурсами організації та постійно мінливим зовнішнім середовищем вимагає розуміння та врахування ключових факторів, що визначають успіх організації. Після того, як визначено найважливіші компетенції, вам потрібно зосередитись на них для постійного вдосконалення роботи організації в цій галузі. Для цього потрібні системи аналізу та обліку показників ефективності, які повинні бути найбільш точними та об'єктивними. 
Мета статті - дослідити підходи до діагностики ефективності стратегії, беручи до уваги взаємозв'язок параметрів, що характеризують різні сфери діяльності підприємства.

Результати дослідження: Провідним підходом до вивчення цієї проблеми був системний підхід, що застосовується при розробці методів оцінки ефективності стратегічного розвитку, що дозволяє визначити пріоритетні фактори стратегічного розвитку компанії. У статті обгрунтовано використання ціннісного підходу в управлінні як методичної основ діагностики ефективності стратегічного розвитку підприємства.

Практична значущість. Результати дослідницької роботи можуть бути корисними для оцінки ефективності стратегічного розвитку підприємства та для визначення пріоритетних факторів стратегічного розвитку та вироблення рекомендацій щодо підвищення вартості бізнесу.

Ключові слова: ефективність, продуктивність, value-based management, підприємництво, стратегії розвитку; ринковий підхід, фінансовий підхід, бізнес.

У сучасних умовах формування ринкових економічних відносин бізнес відіграє важливу роль як у зарубіжних країнах, так і в Україні. Саме підприємництво надає можливості здійснити структурну перебудову економіки і наситити всі види ринків товарами чи послугами в короткі терміни.

Підприємництво - це особливий вид діяльності, і особливість полягає самостійній діяльності за власний рахунок, творчій, систематичній діяльності на власний ризик з метою одержання прибутку або власного доходу.

Згідно чинного законодавства України, підприємництво - це безпосередня самостійна, систематична, здійснювана на власний ризик діяльність 3 виробництва продукції, виконання робіт, надання послуг для отримання прибутку, що здійснюється фізичними та юридичними особами, зареєстрованими як суб'єкти підприємництва у порядку, встановленому законодавством [210]. 
Варто зазначити, що у господарській діяльності підприємництво і бізнес зазвичай використовують як тотожні поняття, але, насправді, «бізнес» - поняття ширше за «підприємництво», адже:

- по-перше: бізнесом вважається здійснення як одноразових бізнесоперацій, так і регулярних комерційних угод в будь-якій сфері діяльності, що націлені на отримання прибутку;

- по-друге: кількість учасників у комерційних операціях перевищує кількість учасників в підприємницькій діяльності, адже остання обмежена кількістю зареєстрованих суб'єктів;

- по-третє: на відміну від підприємництва у бізнесі пряме керівництво не обов'язкове, можлива тільки форма участі, наприклад, через засоби виробництва або гроші.

Отже, можна дійти висновку, що підприємництво та бізнес мають деякі відмінності, але загалом це синонімічні поняття.

Доброва Н.В. зазначає, що “На практиці підприємництво виступає як підприємницький бізнес і залучає тільки свого суб'єкта, а не усіх учасників ринку. Бізнес без підприємництва не існує. Підприємництво - не тільки елемент систему бізнесу, але і фактор його розвитку.” [212, с. 13].

Визначивши деякі відмінності бізнесу від підприємництва, слід навести визначення терміну «бізнес».

Бізнес - це економічна діяльність приватних осіб чи підприємств щодо користування природними ресурсами, виготовлення, купівлі і продажу товарів чи надання послуг в обмін на інші послуги чи гроші для взаємної вигоди декількох сторін.

У науковій літературі виділяють підприємницький, державний та споживчий бізнес. Система бізнесу зображена на мал. 5.6.1. 


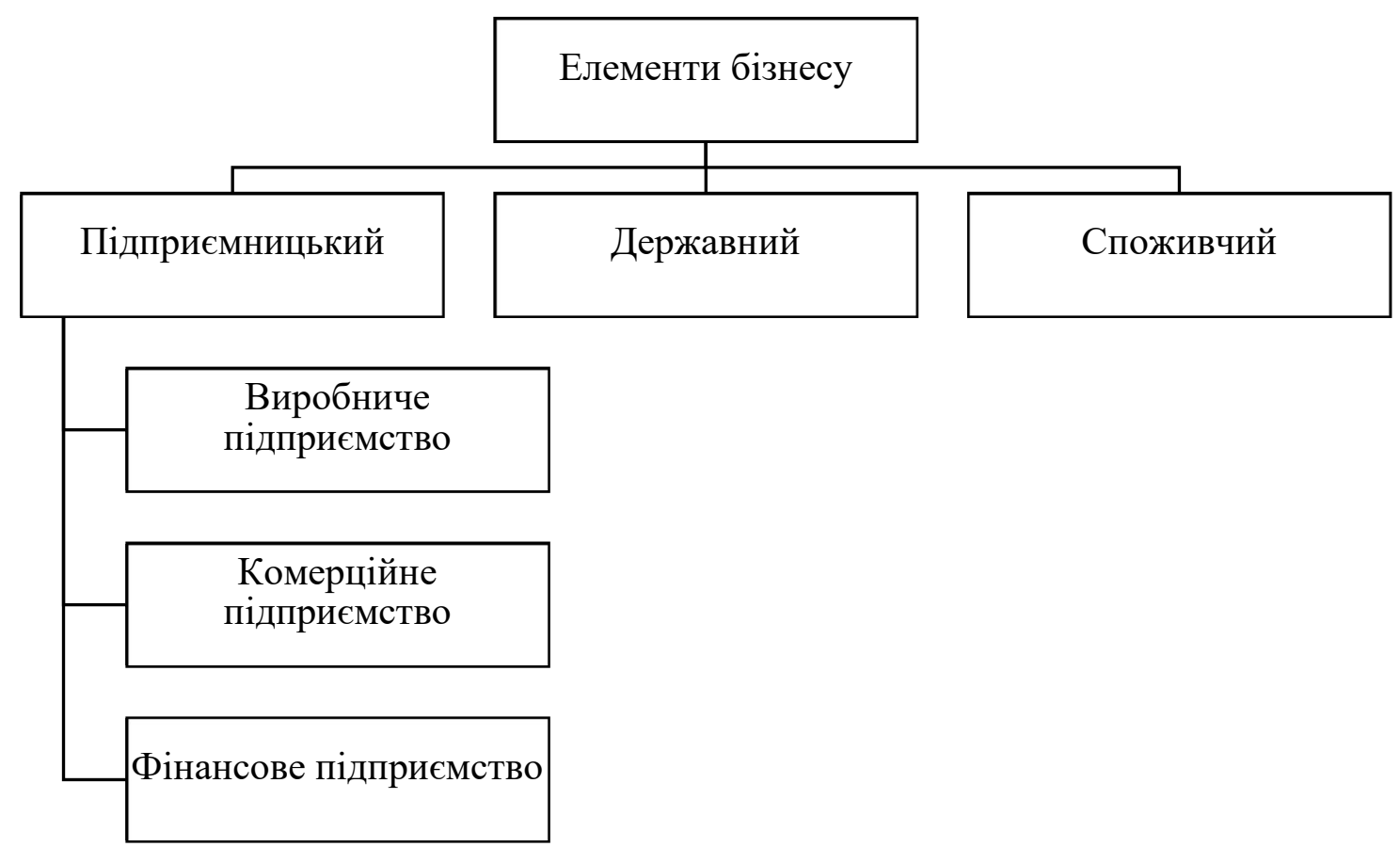

Малюнок 5.6.1. Системи бізнесу як система господарювання Джерело: розроблено автором на основі [215]

Підприємницький бізнес базується на самостійній ініціативі, відповідальності та ініціативній підприємницькій ідеї підприємця. Він поділяється на:

- виробниче підприємство (створення та реалізація товарів чи послуг),

- комерційне підприємство (обмін товарів, послуг через торговельні заклади),

- фінансове підприємництво (обмін вартості через фінансові установи).

Державний бізнес означає вирішення головних загальнодержавних наукових, виробничих, технічних і інших проблем, що мають задовольняти інтереси національної економіки загалом.

Споживчий бізнес - це діяльність громадян 3 метою отримання товарів $\mathrm{i}$ послуг через самостійний пошук постачальників і покупців для одержання максимальної вигоди.

Необхідно вказати, що єдиний підхід до класифікації підприємств на малі, середні та великі на сьогодні відсутній, у кожній країні такі підходи розрізняються. Напевно, що основним критерієм належності підприємств до тієї 
чи іншої категорії є чисельність робітників та обсяги обороту, але при необхідності визначення розміру підприємства можуть враховуватися й інші показники, які коригують і доповнюють вищеназвані критерії. За даними Світового банку існує більше ніж 50 різних критеріїв, за якими розмежовують суб'єктів господарської діяльності на малий, середній та великий бізнес.

Загалом, роль бізнесу полягає у стабільності розвитку економіки держави. Він забезпечує значну частину зайнятості, а звідси і благополуччя населення. Бізнес формує середній клас, беручи участь у поглибленні i розвитку конкуренції.

Як правило, великий бізнес - це трансформація малого бізнесу. Можна навести низку відомих підприємців, що побудували бізнес-імперії з незначних накопичень і геніальних бізнес-ідей. Тому зосередимо свою увагу на малому $\mathrm{i}$ середньому бізнесі 3 позиції значення у вирішені соціально-економічних питань держави.

Бізнес $є$ пріоритетом та рушійною ланкою розвитку будь-якої держави 3 перехідною економікою, як найбільш динамічний елемент ії структури, що оперативно реагує на зміни кон'юнктури ринку й надає ринковій економіці необхідної гнучкості та стійкості.

Значення бізнесу для економіки держави розкривається в таких функціях [214, с.8]:

- формування конкурентного середовища;

- швидко реагуючи на зміни ринкову мінливість, надає ринковій економіці необхідної гнучкості;

- значний внесок бізнесу у науково-технічний прогрес;

- вирішення проблеми зайнятості;

- пом'якшення соціальної напруги і демократизації ринкових відносин.

Рушійною силою відновлення позитивних темпів економічного зростання $\epsilon$ підприємництво, функціонування якого не можливо без фінансових ресурсів. Сьогодні особливо складно початкуючим підприємцям, які роблять перші невпевнені кроки в незнайомому для них середовищі і в умовах несприятливої 
економічної ситуації. Фінансове забезпечення стартового етапу підприємництва повністю забезпечується внутрішніми ресурсами самого підприємця, оскільки інші джерела важкодоступні, за винятком дуже дорогих і ризикованих позик від фізичних осіб або кредитних кооперативів. Створити успішний бізнес в Україні - це і виклик і можливість одночасно. Отже, новостворені малі підприємства проходять декілька етапів фінансування таких як бутстрепінг, фінансування «бізнес-ангелами», венчурне фінансування, фінансування кредитними кооперативами, банківське кредитування. Для вирішення проблеми фінансової підтримки новостворених підприємств необхідно удосконалити механізм фінансово-кредитного сприяння розвитку підприємництва. Одними із основних напрямів цієї підтримки $є$ фінансова допомога міжнародних та українських фінансових організацій та фондів, позики комерційних банків та кредитних спілок, лізинг [213, с. 35].

На основі переваг відриття бізнесу, враховуючи недоліки та можливі ризики обирається з наявних або розробляється унікальна стратегія розвитку бізнесу. Найпоширенішими стратегіями в економічній літературі прийнято вважати базисні або еталонні.

За визначенням Боярської М.О. “Вони відбивають підходи до зростання підприємства та пов'язані зі зміною стану одного чи кількох елементів: продукту, ринку, галузі, положення підприємства всередині галузі, технологію” [211, с. 307].

Стратегії концентрованого зростання полягають у зростанні через модифікацію продукту, не змінюючи галузь чи пошук нового ринку збуту, сподіваючись поліпшити власне положення. Розрізняють такі типи:

- стратегія посилення позицій - маркетингові рішення мають покращити позиції компанії;

- стратегія розвитку ринку - покращення позицій компаній, змінивши ринок, на якому вона буде функціонувати;

- стратегія розвитку продукту - розробка і реалізація товару, не змінюючи ринок. 
Стратегії інтегрованого зростання - зростання компанії за рахунок створення нових структур або придбання власності. Компанія може застосовувати таку стратегію, якщо знаходиться в достатньо міцному бізнесі. Розрізняють такі типи:

- стратегія зворотної вертикальної інтеграції - зростання внаслідок створення дочірніх структур, що здійснюють постачання, або ж приєднання компаній, які вже здійснюють постачання. Це зменшує залежність від встановлення цін постачальниками;

- стратегія прямої вертикальної інтеграції - розширення компанії через створення систем розподілу та продажу. Це підвищує якість роботи з клієнтами.

Стратегія диверсифікованого зростання - це стратегія, яка здійснюється в разі, коли компанія більше не має можливостей для розвитку на освоєному ринку 3 виробленим продуктом. Розрізняються такі види [211, с. 308]:

- стратегія центрованої диверсифікованості (пошук та використання способів модифікації продукту, не змінюючи ринку);

- стратегія горизонтальної диверсифікованості (зміна якості продукту, його модифікація або зміна продукту не змінюючи галузі);

- стратегія конгломеративної диверсифікованості (розширення бізнесу на основі виробництва нового продукту за новими технологіями, реалізуючи на новому ринку).

Стратегію поліпшення якісних показників за рахунок скорочення витрат використовують для пошуку способів заходів, що мають знизити планові витрати підприємства. Розглянемо детальніше дані стратегії в табл.5.6.1

Таблиия 5.6.1. Базові (еталонні) стратегії розвитку бізнесу

\begin{tabular}{|c|c|c|c|}
\hline Стратегіï & Продукти & Ринки & Розвиток \\
\hline \multicolumn{4}{|c|}{ Стратегії концентрованого зростання } \\
\hline Посилення позицій & Без змін & Без змін & $\begin{array}{c}\text { Ресегментування й } \\
\text { репозиціювання }\end{array}$ \\
\hline Розвиток продукту & Новий & Без змін & Інноваційні розробки \\
\hline Розвиток ринку & Без змін & Новий & Маркетинг нових ринків \\
\hline \multicolumn{4}{|c|}{ Стратегії інтегрованого розвитку } \\
\hline $\begin{array}{c}\text { Зворотна вертикальна } \\
\text { інтеграція }\end{array}$ & Новий & Без змін & $\begin{array}{c}\text { Інтеграція } 3 \\
\text { постачальниками }\end{array}$ \\
\hline $\begin{array}{c}\text { Пряма вертикальна } \\
\text { інтеграція }\end{array}$ & Новий & Без змін & $\begin{array}{c}\text { Інтеграція з } \\
\text { торговельними } \\
\text { постачальниками }\end{array}$ \\
\hline
\end{tabular}




\begin{tabular}{|c|c|c|c|}
\hline \multicolumn{4}{|c|}{ Стратегії диверсифікованого зростання } \\
\hline $\begin{array}{c}\text { Горизонтальна } \\
\text { диверсифікованість }\end{array}$ & Новий & Без змін & $\begin{array}{c}\text { Освоєння нової } \\
\text { технології на старому } \\
\text { виробництві для нового } \\
\text { продукту }\end{array}$ \\
\hline $\begin{array}{c}\text { Конгломератна } \\
\text { диверсифікованість }\end{array}$ & Новий & Новий & $\begin{array}{c}\text { Нові технології на } \\
\text { новому виробництві для } \\
\text { нового продукту й } \\
\text { нового ринку } \\
\end{array}$ \\
\hline $\begin{array}{c}\text { Центрована } \\
\text { диверсифікованість }\end{array}$ & Новий & Без змін & $\begin{array}{c}\text { Розширення старого } \\
\text { виробництва для } \\
\text { випуску нового } \\
\text { продукту } \\
\end{array}$ \\
\hline \multicolumn{4}{|c|}{ Стратегія поліпшення якісних показників } \\
\hline $\begin{array}{c}\text { Стратегія поліпшення } \\
\text { якісних показників за } \\
\text { рахунок скорочення витрат }\end{array}$ & Освоєниї & Освоєний & $\begin{array}{c}\text { Реалізація стратегії } \\
\text { лідерство за витратами }\end{array}$ \\
\hline
\end{tabular}

Джерело: складено автором

Отже, головна мета стратегій розвитку бізнесу - це забезпечення впровадження нових технологій i змін в діяльності підприємства шляхом впровадження заходів розподілу ресурсів, зменшення витрат, адаптування до мінливості оточуючого середовища, i плануванні проведення змін у господарській діяльності у майбутньому.

Стратегія розвитку бізнесу обирається на основі аналізу зовнішнього середовища та внутрішніх перспектив компанії, враховуючи непередбачені ринкові зміни. Вона має складатися не тільки виконання визначеного плану, а також із реакції на зміни в оточуючому іiі середовищі.

Перш за все, хочеться наголосити, що саме вибір стратегій для розвитку кожного бізнесу підприємства є основою стратегічного менеджменту. Звернемо увагу на підхід, який оцінює стратегії базуючись на визначенні ряду нормативних та фактичних показників і встановленні співвідношення між ними для виробничих підприємств, діяльність яких проходить на ринках 3 інтенсивною конкуренцією, який передбачає реалізацію наступних етапів:

- формування переліку показників визначення економічного зростання;

- встановлення нормативних співвідношень між темпами зростання цих показників, тобто побудову нормативної структури показників відповідно до конкретних умов; 
- вибір нормативної структури показників відповідно до особливостей ситуації;

- визначення фактичної структури показників, що відображає реальний стан організації;

- оцінку відповідності між фактичною та нормативною структурою показників;

- виявлення зовнішніх і внутрішніх чинників, які визначають фактичну структуру показників і ступінь їхнього впливу;

- формулювання висновків про результативність діючих у минулому стратегій і доцільність розроблення нової стратегії.

Здійснивши аналіз плюсів та мінусів основних підходів, що було розглянуто вище, до оцінки обраної стратегії, можна дійти висновку, що кожен 3 таких підходів може застосовуватися тільки за конкретних умов і має ряд значних обмежень. Більшість підходів дають можливість провести не тільки кількісну, а й якісну оцінку однієї з обраних стратегій, що являється достатньо суб'єктивною.

3 усіх проаналізованих підходів до оцінювання стратегії можна виділити як найбільш доцільний та повноцінний останній підхід, а саме - оцінка, що заснована на визначенні ряду показників фактичних та нормативних i встановлення співвідношення між ними, через те що у порівнянні з іншими підходами він має набагато більше суттєвих переваг. В цей же час не можна ігнорувати ряд виділених недоліків обраного підходу. Проаналізовані мінуси цього підходу були взяті до основи пропозицій автора щодо його вдосконалення. Можна виділити критерії оцінки стратегії іншим чином відповідно до двох підходів - фінансового та ринкового (мал. 5.6.2). 


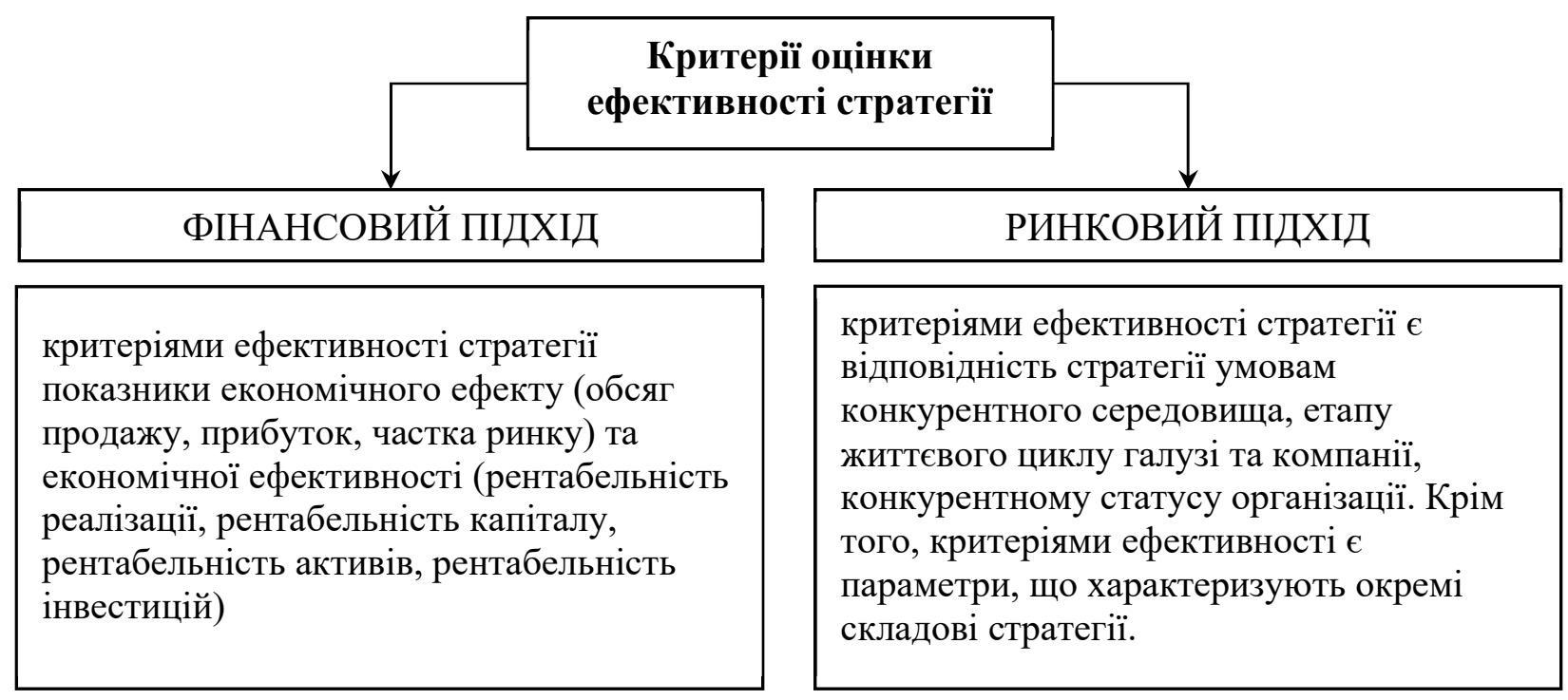

Малюнок. 5.6.2. Критерії оцінки ефективності стратегії підприємства

Джерело: [216, с. 112]

Так, бачимо, що перший підхід, в більшості базується на розрахунку внутрішніх показників діяльності підприємства 3 метою їхнього подальшого аналізу та оцінки, щодо другого - то такий підхід $є$ ширшим за перший, та охоплює аналіз конкурентного середовища, що має на увазі оцінку всіх найбільших конкурентів компанії та їх діяльності.

Однак, на нашу думку, ринковий підхід не є досконалим. Він може лише порівняти ефективність діяльності підприємства 3 іншими на ринку, однак повністю оцінити ефективність самого підприємства та його подальший розвиток, за допомогою ринкового підходу неможливо.

Цільовий підхід, підхід, заснований на теорії систем, багатопараметричний підхід до оцінки можна виділити серед підходів, спрямованих на оцінку ефективності діяльності підприємства (включаючи його стратегічну ефективність),

Цільовий підхід - це погляд на ефективність, який підкреслює центральну роль цілі як критерію оцінки результативності. Відповідно до цього підходу організація існує для досягнення певних цілей, а ступінь реалізації завдань відображає ступінь іiі ефективності. Підхід до оцінки ефективності систем, заснований на теорії, передбачає аналіз організаційної поведінки, передбачаючи 
розподіл основних елементів ("вхід", "процес", "вихід") у системі та іiі адаптацію до високого рівня системних умов. Теорія систем акцентує увагу на тому, що виживання організації залежить від іiі здатності адаптуватися до вимог навколишнього середовища. Виконання цих вимог залежить від того, чи знаходиться повний цикл "вхід - процес - вихід" в центрі уваги керівництва. Отже, критерії повинні відображати стратегічну ефективність цих положень. Цей підхід пояснює, чому ресурси слід використовувати для діяльності, яка не пов'язана безпосередньо з досягненням організаційних цілей.

Багатопараметричний підхід передбачає оцінку задоволеності працівників та груп, що беруть участь в організації.

Використання традиційної фінансової моделі для оцінки ефективності ринку базується на типі економічного мислення, згідно з яким на ефективність компанії впливають фактори внутрішнього середовища (цілі, організаційна структура, завдання, використовувана технологія та людські ресурси). Отже, ефективність роботи досягається шляхом прийняття стратегічних та оперативних рішень на основі поточних можливостей організації.

Вартість фінансової моделі відрізняється від традиційної, враховуючи існуючі альтернативи та пов'язані $з$ цим ризики. Ця модель являє собою інтегровану оцінку всіх аспектів організації вартості бізнесу через результативність.

Таким чином, ми можемо зробити висновок, що в якості методичних основ оцінки ефективності стратегії доцільно використовувати концепцію управління на основі вартості (VBM), що орієнтується на забезпечення стійкого розвитку підприємства в довгостроковому періоді.

Відповідно до концепції VBM критерієм ефективності управління підприємством є підвищення ринкової вартості підприємств. Приріст вартості бізнесу надає бізнесу можливість створювати економічні вигоди. У цьому випадку економічний прибуток створюється шляхом злиття капіталу (функція фінансування) та їх вкладення в механізми отримання певного прибутку бізнесу 
(функція інвестування). Компанію в цілому можна розглядати як сукупність механізмів створення вартості.

Економічний прибуток - найпоширеніший показник ефективності організації, який представляє величину прибутку після покриття всіх витрат організації, як операційних, так i фінансових, пов'язаних із виконанням зобов'язань перед кредиторами та власниками. Також включаються фінансові витрати, пов'язані з обслуговуванням власного капіталу, у сумі, що відповідає вимогам власників повернути вкладений капітал, незалежно від розміру фактично виплачених дивідендів.

Для визначення ефективності процесу додавання вартості до основних характеристик стратегічної ефективності можуть бути використані: ефективність та продуктивність. У цьому випадку результативність може бути виражена як здатність ефективно створювати додану вартість у процесі основної та інвестиційної діяльності (ROIC), а продуктивність - через оцінку здатності генерувати позитивні фінансові результати, як здатність ефективно використовувати вкладений капітал (ROIC-WACC).

Таким чином, ефективність визначає рівень досягнення цілей i запланованих результатів у виробничо-господарській, маркетинговій, фінансовій, соціальній, інноваційній та інших видах діяльності підприємства.

Ефективність може бути підвищена за рахунок вдосконалення продуктів або послуг (результатів), які компанія пропонує ринку. Залежно від ситуації ефективність може бути покращена шляхом переробки процесів або переробки продуктів (послуг) відповідно до вимог до продуктивності, визначених зовнішніми та / або внутрішніми замовниками та споживачами.

Продуктивність - це інтегрований багатофакторний індекс, який поєднує навички та інтереси персоналу, рівень технологій, якість продукції, якість управління, маркетинг, соціальне та економічне середовище. Найкраще поєднання факторів виробництва визначає найкраще використання ресурсів, їх найкращі показники. На продуктивність праці в першу чергу впливають внутрішні фактори: технологія, організація виробництва та управління. Таким 
чином, необхідно враховувати макроекономічні фактори, які можуть сприяти або перешкоджати поліпшенню результативності. Це включає державну політику, економічну та соціальну стратегію та напрямок їх реалізації, діловий цикл та міжнародну конкуренцію, природне середовище, географічні та кліматичні особливості, демографічні (структурні та соціальні) зміни.

Продуктивність як кількісний параметр оцінки бізнес-процесу, це відношення обсягу вироблених товарів або послуг, що продаються організацією, до витрат на їх створення. Він відображає ефективне використання ресурсів (праці, капіталу, матеріалів, енергії, інформації) у бізнес-процесах організації.

Компанії різних галузей працюють у надзвичайно складних, невизначених та динамічних сучасних соціальних та економічних умовах. Формування глобального інформаційного ринку, де ви можете отримати майже миттєвий доступ до інформації про будь-які товари від будь-якого постачальника у всіх регіонах світу, спричинило різке посилення конкуренції між суб'сктами господарювання. Інерційна організація управління бізнесом 3 жорсткою структурою не дозволяє швидко реагувати на постійно мінливі вимоги ринку. Основною умовою сталого розвитку в конкурентній боротьбі є здатність суб'єкта господарювання до довгострокового бачення та послідовного впровадження різноманітних інновацій в асортименті товарів та послуг, менеджменті, технологіях тощо. Для досягнення конкурентної переваги підприємство повинно бути кращим за своїх конкурентів не лише з точки зору всіх бізнес-процесів, але й загальної ефективності. Чітка стратегія, виражена в цілях та показниках бізнеспроцесів, повинна бути спрямована на задоволення очікувань споживачів та акціонерів (інвесторів). Цей підхід від загального до конкретного (зверху вниз) виявляє абсолютно нові бізнес-процеси, в яких, і завдяки яким компанія зможе досягти досконалості. 